\title{
骨肉腫・術前治療の各種効果判定法
}

\begin{tabular}{|c|c|c|c|c|c|}
\hline 平 & 野 & & 徹・岩 & 崎 & 勝 \\
\hline 貞 & 松 & 俊 & 弘・榎 & 本 & \\
\hline 鈴 & 木 & 良 & 平 & & \\
\hline
\end{tabular}

\section{Clinical Evaluation for Predicting the Response of Osteosarcoma to Preoperative Treatment}

by

\section{Toru Hirano, Katsuro Iwasaki, Toshihiro Sadamatsu, Hiroshi Enomoto and Ryohei Suzuki}

Department of Orthopaedic Surgery, Nagasaki University School of Medicine, Nagasaki

The response of osteosarcoma to preoperative treatment, which was classified by the degree of histologic tumor necrosis as good (4 cases), poor (5 cases) and fair (one case), was evaluated in 10 cases by using the value of serum alkaline phosphatase (SALP), conventional radiography, ${ }^{99 m} \mathrm{Tc}-$ MDP scintigraphy, computed tomography (CT) and angiography before and after the treatment.

All of the good responding cases showed the findings of a decreased uptake in ${ }^{99 \mathrm{~m}} \mathrm{Tc}-\mathrm{MDP}$ scintigraphy. A shrinkage of soft tissue mass on CT was seen in only 2 good responding cases. Angiography in 3 good and one fair cases revealed a decrease in tumor vascularity. The change of sALP value and radiographic findings were not correlated with the degree of histologic tumor necrosis.

Therefore, ${ }^{99 \mathrm{~m}} \mathrm{Tc}-\mathrm{MDF}$ scintigraphy, $\mathrm{CT}$ and angiography would be of use for predicting the response of osteosarcoma to preoperative treatment.

\section{は じめに}

近年，四肢原発の骨肉腫の治療で，患肢温存のため 広汎切除が盛んに行われている ${ }^{3)}$.この患肢温存手術に おける切除縁設定に際して, 局所再発がないように, また術後患肢機能がなるべく温存出来るようにするた めには，化学療法や放射線療法などの術前治療の効果 を適確に把握する必要がある。

そのための検査法として, 血清アルカリフォスファ ターゼ值 (sALP 值)の測定, 単純X線, CT スキャン, 骨シンチ，血管造影などが知られているが，その有用 性については必ずしも一定の見解が得られていな (224)6110).そこでわれわれは，骨肉腫に対する術前治療 の効果判定のため，それぞれの検査法の有用性につい

て比較検討した.

\section{対象および方法}

対象は 1984 年以降当教室で治療した骨肉腫 10 症例 である．発生部位および外科的治療法を表 1 亿示す。 患肢温存手術を行ったのは 10 例のうち 8 例である.術

表1 骨肉腫症例の発生部位と外科的治療法

\begin{tabular}{|c|c|c|}
\hline 部位 & 患肢温存 & 切・離断 \\
\hline $\begin{array}{l}\text { 上腕骨近位 部 } \\
\text { 腸 } \\
\text { 大腿骨近位部 } \\
\text { 大腿骨遠位部 } \\
\text { 脛骨近 位 部 }\end{array}$ & $\begin{array}{l}1 \\
1 \\
5 \\
1\end{array}$ & 1 \\
\hline
\end{tabular}


表 2 現在当教室で行っている術前治療と特殊検査

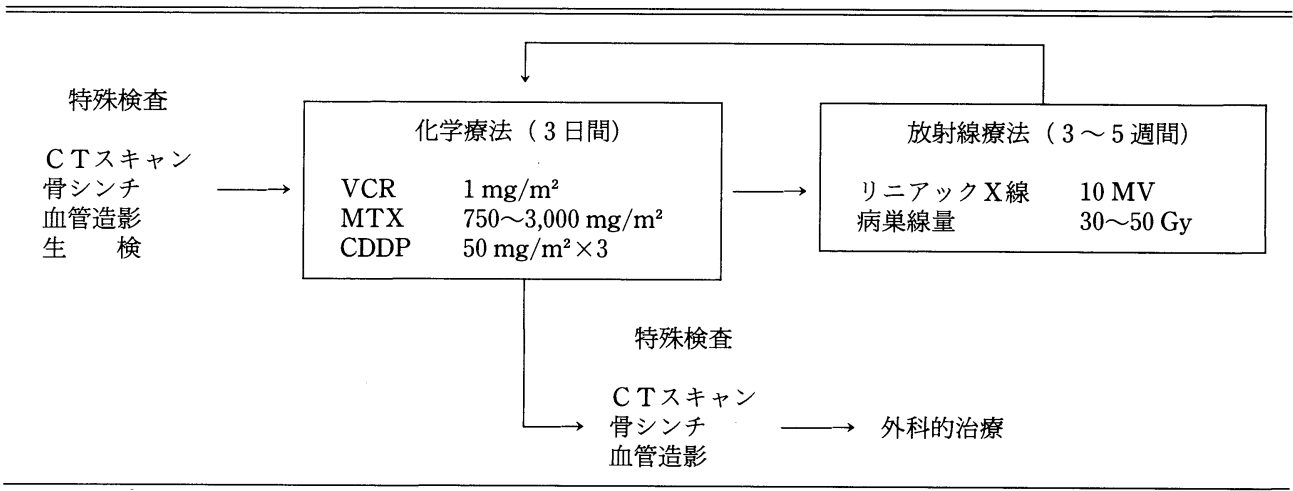

表 3 骨肉腫症例に対する術前治療の組織学的効果

\begin{tabular}{|c|c|c|c|}
\hline \multicolumn{2}{|c|}{ 組織学的治療効果 } & 症 例 数 & 壊死の割合（\%） \\
\hline 著 & 効 & 4 & $83 \sim 95$ \\
\hline 有 & 効 & 5 & $62 \sim 75$ \\
\hline 無 & 効 & 1 & 37 \\
\hline
\end{tabular}

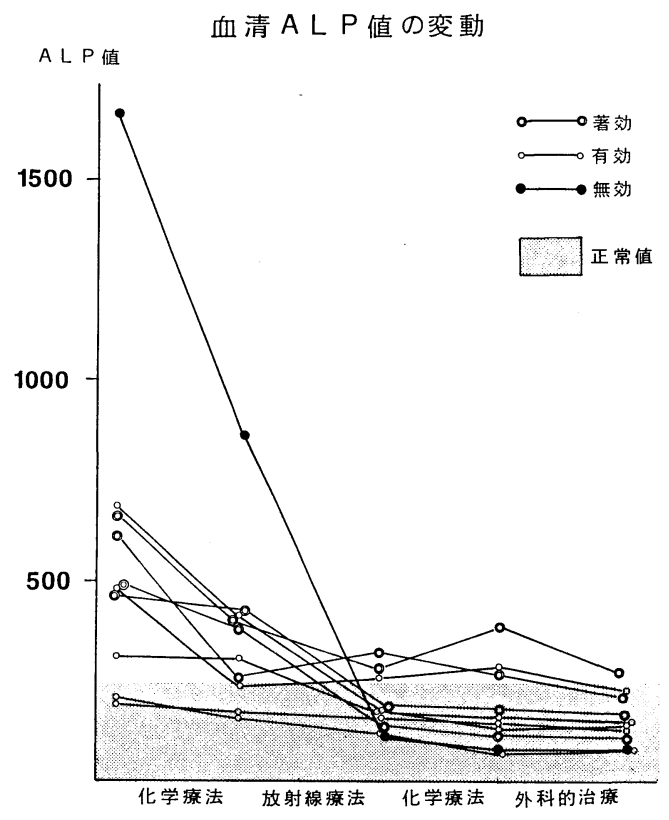

図 1 表 2 に示す術前治療による骨肉腫 10 症例の血清 ALP の值の変動.

前治療として，メソトレキセート (MTX), シスプラ チン $(\mathrm{CDDP})$ などを主体にした全身的化学療法を 2 サ イクル行い1), その間にリニアック X線を $30 \mathrm{~Gy}$ から 50 Gy 照射した（表 2 ）.
術前治療効果判定のための検查法として, SALP 值の 測定と単純 $\mathrm{X}$ 線は定期的に, 骨シンチ, CT スキャン, 血管造影は治療開始前と終了後に行った. それらの有 用性を検討するため, 術前治療前後の検查所見の変化 を調べ,これと手術時摘出した腫瘍の組織学的所見と を対比した。

組織学的な治療効果の判定には Picci et al. ${ }^{6)}$ の評価 法を使用し, 腫沮の壊死の割合から, 著効 (壊死率 80 $\%$ 以上), 有効 (壊死率 50 80\%), 無効 (壊死率 $50 \%$ 以下）に分けた.

表 3 に対象 10 症例の組織学的治療効果を示す.

結果

骨肉腫 10 症例の術前治療開始前では, SALP 值は 194 IU から 1,660 IU まで非常にばらつきが大きかった が, 治療中は経過とともに順調に下降した。術前治療 終了時には, その值は 89 IU から 391 IU の間にいずれ の症例も低下しており, 組織学的効果判定の著効, 有 効，無効との間に相関関係はなかった（図 1 ).

次に単純 X線像では腫瘍の硬化性変化の出現につい て観察した。この硬化性変化は著効例のすべてを含む 7 例に認められた(図 2 ). しかし無効例でも,この所 見は出現しており, 逆に有効例でこの所見がみられな かったものが 3 例あった(図 3 ). 骨シンチでは, 著効 例のすべてに ${ }^{99 \mathrm{~m} T \mathrm{~T}-\mathrm{MDP}}$ 取り込みの低下がみられた (図 4 ).これに対して有効例では, その所見に差はな く(図 5 ), 無効例では ${ }^{99 \mathrm{~m}} \mathrm{Tc}-\mathrm{MDP}$ 取り込みの増加領 域が拡大する傾向を示した（表 4 ）.

CT スキャンによる効果判定の所見である軟部腫瘤陰 影の縮小は著効の 2 例にみられた。しかし変化がなか 


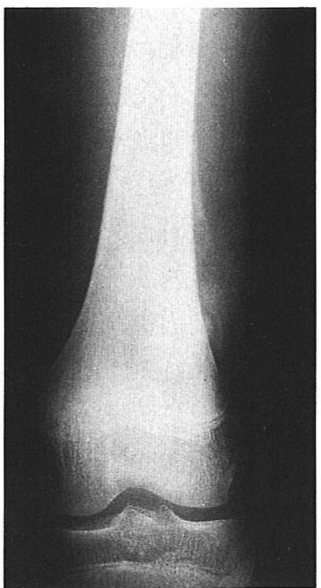

A

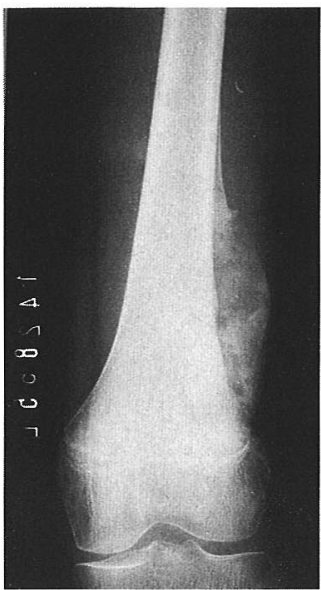

B

図 214 才, 男性. 左大腿骨遠位部原発の骨肉腫。著 効例の単純 X線像。 $\mathrm{A}$ : 術前治療開始前, $\mathrm{B}$ : 術前治療終了後. 著明な硬化性陰影の出現がみ られる。

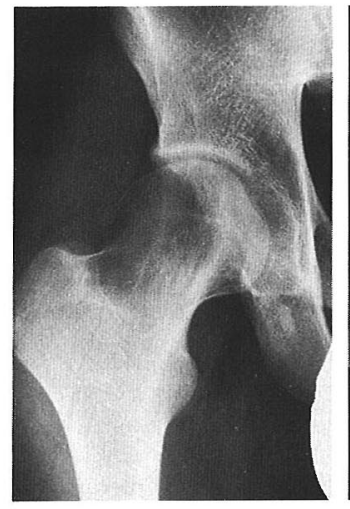

A

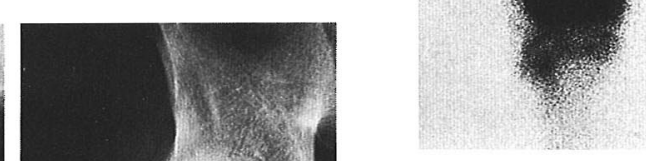

A

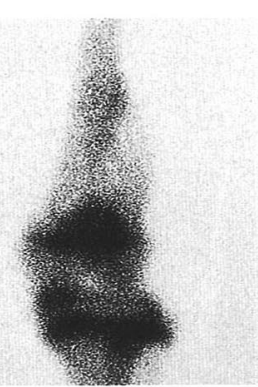

B

図 4 図 1 と同一症例の骨シンチ像。A：術前治療開 始前, B : 術前治療終了後。 ${ }^{99 \mathrm{~m}} \mathrm{Tc}-\mathrm{MDP}$ の取り 込みが著しく低下している。

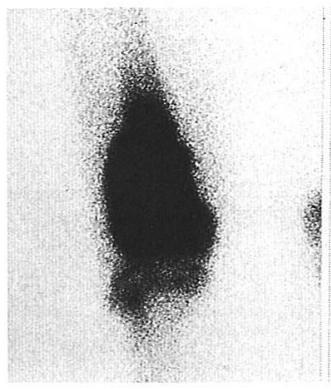

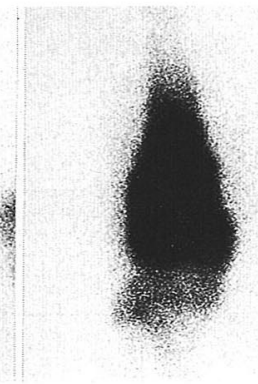

B

図 516 才，女性。左大腿骨遠位部原発の骨肉腫. 有 効例の骨シンチ像。A：術前治療開始前, B : 術前治療終了後。両者間に所見の差はみられな い.

表 4 組織学的治療効果と骨シンチ所見の比較

\begin{tabular}{cc|c|c}
\hline \multirow{2}{*}{ 治 療 効 果 } & \multicolumn{2}{|c}{${ }^{99 m} \mathrm{Tc}-\mathrm{MDP}$ 取り込み } \\
\cline { 3 - 4 } & & 減 少 & 不 変 \\
\hline 著 & 効 & 4 & \\
有 & 効 & & 5 \\
無 & 効 & & 1 \\
\hline
\end{tabular}

造影による判定が出来なかった。判定可能な 7 例のう ち, 著効 3 例と有効 1 例で新生血管の著しい減少がみ られた（図 6)。この有効例は壊死率 $74 \%$ と著効に近 い効果を示した症例であった。しかし無効例と有効の 2 例では，新生血管の減少はみられなかった（表 5 ).

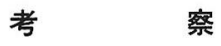

骨軟部悪性腫瘍に対する患肢温存治療において，再 


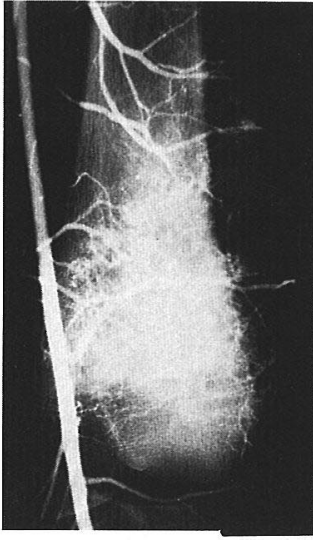

A

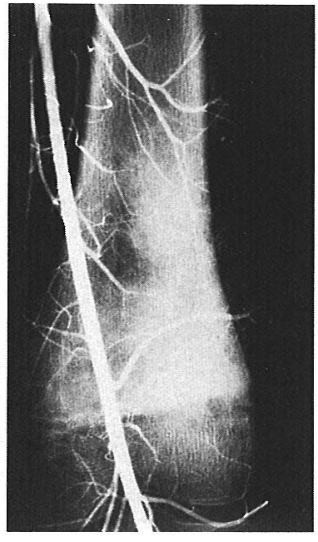

B
図 615 才，男性。左大腿骨遠位部原発の骨肉腫。著 効例の血管造影像. A : 術前治療前, B : 術前 治療終了後。腫瘍新生血管は減少している。

表 5 組織学的治療効果と血管造影所見の比較

\begin{tabular}{cc|c|c|c}
\hline \hline \multirow{2}{*}{ 治療効果 } & \multicolumn{3}{|c}{ 腫瘍 新 生 血管 } \\
\cline { 3 - 5 } & & 減 少 & 不 変 & 判定不能 \\
\hline 著 & 効 & 3 & & 1 \\
有 & 効 & 1 & 2 & 2 \\
無 & 効 & & 1 & \\
\hline
\end{tabular}

発防止のため根治的広沉切除術あるいはそれに準じた 切除法が Enneking や川口らによって提唱され ${ }^{3 / 5)}$ ，広 く行われている。一方, 動脈内注入法などによる強力 な化学療法や放射線療法を併用した術前治療の進歩に よって，切除縁を縮小する試みもなされている ${ }^{8999}$. し かし骨軟部悪性腫瘍の組織型によって, 術前治療の効 果に差があり，また同じ組織型でも症例によってその

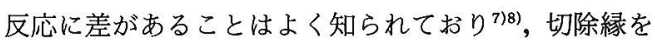
縮小した患肢温存治療を確実にかつ効果的に行うため には，術前治療の効果を正確に把握する必要がある。

本研究では骨肉腫に対象をしぽって, 術前治療の効 果判定について検討した。現在その効果判定に有用な 所見と考元られているのは, sALS 值の変動, 単純X線 における硬化性変化の出現, CT スキャンでの軟部腫瘍 陰影の縮小, 骨シンチの ${ }^{99 m} \mathrm{Tc}-\mathrm{MDP}$ 取り込みの減少そ して血管造影における腫旿新生血管の減少などであ $3^{224)(6) 100}$.

しかし,これらの所見の有用性について, 総合的に

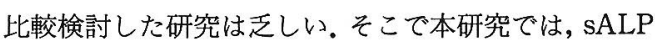

值，単純X線，骨シンチ, CT スキャン，血管造影の変 化のうち, どれがもっとも組織学的効果の程度と相関 しているかを検討した。その結果, 骨シンチ, CT スキ ヤン, 血管造影所見の変化がもっとも組織学的効果の 程度と相関している事がわかった。とくに骨シンチと 血管造影は有用性が高く, 両者の変化からその組織学 的効果を判定する事が可能と考えられた。

以上より, 骨シンチ, CT スキャン, 血管造影は各々 の骨肉腫症例について, 術前治療効果判定のために有 用な検查法であり，骨肉腫手術に際して切除縁決定な どの指標になり得ることが示唆された。

\section{ま と め}

1. 骨肉腫 10 症例を用いて, 術前治療・効果判定の ための検査法の有用性を比較検討した。

2.その結果, 以下のことがわかった。

1) SALP 值の変動や単純 X線に抢ける硬化性変化 は，術前治療が無効であった症例でも著効例と同様に 認められたことから，その効果判定法としての有用性 にそしかった。

2）骨シンチにおける ${ }^{99 \mathrm{~m}} \mathrm{Tc}-\mathrm{MDP}$ 取り込みの減少, CT スキャンでの軟部腫瘍陰影の縮小は著効例だけで出 現していた。さらに血管造影では有效例と著効例で腫 湟新生血管の著しい減少がみられた。

3. 以上より,骨シンチ, CT スキャンおよび血管造 影所見を組み合わせて, 総合的に検討することにより， 術前治療効果を適格に判定出来ることが示唆された。

\section{参 考 文 献}

1) Bacci, G. et al. : Neoadjuvant chemotherapy for high grade osteosarcoma of the extremities: Is a good response to preoperative treatment an indication to reduce postoperative chemotherapy? Chemioterapia. 5 : 140-143, 1986.

2) Chuang, V.P. et al.: Radiographic and angiographic changes in osteosarcoma after intraarterial chemotherapy. Am. J. Radiol. 139 : 1015-1069, 1982.

3) Enneking, W.F.: A system of staging musculoskeletal neoplasms. Clin. Orthop. 204 : 9-24, 1986.

4) 古瀬清夫・他：骨肉腫に対する術前化学療法の効果判 定とその問題点. 第 21 回骨・軟部腫掦研究会抄録集, 1988.

5）川口智義・他：悪性軟部腫湟の根治的広切法について の検討. 臨整外, $17: 1192-1206,1982$.

6) Mail, J. T. et al.: Response of osteosarcoma to preoperative intravenous high-dose Methotrexate 
chemotherapy: CT evaluation. Am. J. Radiol. 144 : 89-93, 1985.

7) Picci, P. et al.: Histologic evaluation of necrosis is osteosarcoma induced by chemotherapy. Ragional mapping of viable and nonviable tumor. Cancer 56 : 1515-1521, 1985.

8) Rosen, G. et al. : Chemotherapy, en bloc resection, and prosthetic bone replacement in the treatment of osteogenic sarcoma. Cancer 37 : 1-11, 1976.

9）柴田大法・他：術前化学療法による surgical staging の改変に関する臨床病理学的検討. 第 21 回骨・軟部腫 瘍研究会抄録集, 1988 .

10) Sommer, H. et al. : Histomorphometric changes of osteosarcoma after chemotherapy. Correlation with ${ }^{99 m} \mathrm{Tc}$ methylene diphosphonate functional imaging. Cancer 59: 252-258, 1987. 